medRxiv preprint doi: https://doi.org/10.1101/2021.12.20.21268000; this version posted December 27, 2021. The copyright holder for this preprint (which was not certified by peer review) is the author/funder, who has granted medRxiv a license to display the preprint in It is made available under a CC-BY 4.0 International license.

\title{
ESBL plasmids in Klebsiella pneumoniae: diversity, transmission, and contribution to infection burden in the hospital setting
}

Jane Hawkey*1, Kelly L Wyres*1, Louise M Judd ${ }^{1}$, Taylor Harshegyi ${ }^{1}$, Luke Blakeway ${ }^{1}$, Ryan R Wick $^{1}$, Adam W J Jenney ${ }^{2}$, Kathryn E Holt ${ }^{1,3}$

*J. Hawkey and K.L Wyres contributed equally to this manuscript.

${ }^{1}$ Department of Infectious Diseases, Central Clinical School, Monash University, Victoria, Australia

${ }^{2}$ Microbiology Unit \& Department of Infectious Diseases, The Alfred Hospital, Melbourne, Victoria, Australia

${ }^{3}$ Department of Infection Biology, London School of Hygiene and Tropical Medicine, London, United Kingdom

\section{Keywords}

ESBL; plasmids; Klebsiella pneumoniae; third-generation cephalosporin resistance

\section{Running title}

Diversity and transmission of ESBL plasmids among Enterobacteriaceae and their contribution to infection burden

\section{Corresponding author contact details}

jane.hawkey@monash.edu

kat.holt@Ishtm.ac.uk

\section{0-word summary}

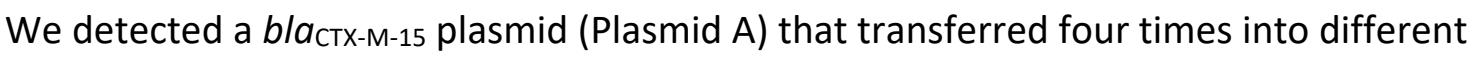
Klebsiella lineages, causing $50 \%$ of ESBL episodes during the initial study. Three Plasmid Apositive strains persisted locally 3-6 years later, accounting for $21 \%$ of ESBL+ infections. 
medRxiv preprint doi: https://doi.org/10.1101/2021.12.20.21268000; this version posted December 27,2021 . The copyright holder for this preprint (which was not certified by peer review) is the author/funder, who has granted medRxiv a license to display the preprint in It is made available under a CC-BY 4.0 International license .

\begin{abstract}
Background

Resistance to third-generation cephalosporins, often mediated by extended-spectrum betalactamases (ESBLs), is a considerable issue in hospital-associated infections as few drugs remain for treatment. ESBL genes are often located on large plasmids that transfer horizontally between strains and species of Enterobacteriaceae and frequently confer resistance to additional drug classes. While plasmid transmission is recognised to occur in the hospital setting, the frequency and impact of plasmid transmission on infection burden, compared to ESBL+ strain transmission, is not well understood.
\end{abstract}

\title{
Methods
}

We sequenced the genomes of clinical and carriage isolates of Klebsiella pneumoniae species complex from a year-long hospital surveillance study to investigate ESBL burden and plasmid transmission in an Australian hospital. Long-term persistence of a key transmitted $\mathrm{ESBL}+$ plasmid was investigated via sequencing of ceftriaxone-resistant isolates during four years of follow-up, beginning three years after the initial study.

\section{Results}

We found 25 distinct ESBL plasmids. One (Plasmid A, carrying bla similar to pKPN-307) was transmitted at least four times into different Klebsiella species/lineages and was responsible for half of all ESBL episodes during the initial one-year study period. Three of the Plasmid A-positive strains persisted locally 3-6 years later, and Plasmid A was detected in two additional strain backgrounds. Overall Plasmid A accounted for $21 \%$ of ESBL+ infections in the follow-up period.

\section{Conclusions}

Whilst ESBL plasmid transmission events were rare in this setting, they had a significant and sustained impact on the burden of ceftriaxone-resistant and multidrug-resistant infections. 
medRxiv preprint doi: https://doi.org/10.1101/2021.12.20.21268000; this version posted December 27, 2021. The copyright holder for this

preprint (which was not certified by peer review) is the author/funder, who has granted medRxiv a license to display the preprint in perpetuity.

It is made available under a CC-BY 4.0 International license.

\section{Introduction}

Healthcare-associated infections (HAIs) are a top global health priority. In industrialised countries, the HAl burden is greater than that of all other communicable diseases combined [1]. Antimicrobial resistant (AMR) HAls are particularly problematic as they reduce treatment options, and the World Health Organisation recognises third-generation cephalosporin-resistant (3GCR) and carbapenem-resistant Gram-negative bacterial HAI pathogens, including Klebsiella pneumoniae and Escherichia coli, as a critical threat [2]. These resistance phenotypes are typically mediated by horizontally acquired extendedspectrum beta-lactamase (ESBL) and carbapenemase genes, encoded on large plasmids that circulate amongst different species. As a result, transmission of AMR HAls within healthcare settings can result from transmission of a resistant strain, or of a resistance-encoding plasmid between strains of the same or different species [3]. K. pneumoniae is a well-known reservoir of AMR plasmids, recognised for its ability to acquire and transfer these plasmids across its population and into other species $[4,5]$.

Genomics is a powerful approach for investigating transmission of AMR HAls, which is gradually being implemented to detect and contain transmission of AMR pathogens [6-8]. Lengthy hospital outbreaks (3-6 years) have been documented due to plasmid transmission (frequently involving Klebsiella) [9-11], and metagenomic studies show that AMR plasmids are ubiquitous in hospitals [12]. However, genomics surveillance studies typically focus on identifying strain transmission rather than plasmid transmission, and the contribution of the latter to HAl burden is poorly understood.

Here we examine the diversity and transmission of ESBL plasmids in $K$. pneumoniae species complex (KpSC) isolates collected during a one-year surveillance period in a large tertiary hospital and referral network in Melbourne, Australia [13-15], and explore the contribution of ESBL plasmid transmission to infection burden in both the short term (year-long study period) and longer term (4 years of follow-up, beginning 3 years after the primary study).

\section{Methods}

\section{Ethical approval}

The primary study was approved by the Alfred Health Human Research Ethics Committee (AHHREC), Project numbers \#550/12 (19 February 2013) and \#526/13 (10 December 2013). Analysis of clinical isolates 2017-2020 was approved by AHHREC, Project number \#371/19 (2 July 2019).

\section{Specimen collection}

The primary KpSC collection comprised 440 Klebsiella pneumoniae, Klebsiella variicola and Klebsiella quasipneumoniae isolated at the Alfred Hospital Microbiological Diagnostic Laboratory from patients at hospitals in the Alfred Health network, Melbourne, during a prospective surveillance study (KASPAH) between April 2013 and March 2014

(Supplementary Table 1). KASPAH study protocols are reported elsewhere [13-15]. Briefly, gut carriage (colonising) isolates $(n=108)$ were cultured from rectal screening swabs in either the Alfred Hospital ICU (33\% of patients screened) [13] or Caulfield Hospital geriatric wards (31\% screened) [14]. Infection isolates ( $n=332$ ) represent all KpSC clinical isolates identified by standard diagnostic protocols across the study period [15]. In January to March 
medRxiv preprint doi: https://doi.org/10.1101/2021.12.20.21268000; this version posted December 27, 2021. The copyright holder for this preprint (which was not certified by peer review) is the author/funder, who has granted medRxiv a license to display the preprint in perpetuity.

It is made available under a CC-BY 4.0 International license .

2014, 3GCR Gram-negative carriage and infection isolates were also collected from Alfred Hospital ICU patients as described previously [16], and those identified as Enterobacteriaceae were included here $(n=74)$. All isolates were subjected to antimicrobial susceptibility testing using Vitek2 GN AST cards (bioMérieux) and interpreted using EUCAST cut-offs (2020).

To determine whether KpSC lineages harbouring a plasmid of interest (Plasmid A) during the primary study period persisted 3-6 years later, we interrogated all 3GCR KpSC clinical isolates identified by the same diagnostic laboratory between March 2017 and December 2020 ( $n=450$, identified as K. pneumoniae or K. variicola by MALDI-TOF (Bruker) and resistant to ceftriaxone (MIC $\geq 2 \mathrm{mg} / \mathrm{mL}$ )).

\section{Whole-genome sequence (WGS) analysis}

DNA was extracted and sequenced using the Illumina platforms as previously reported [1316]. A subset $(n=70)$ of ESBL+ isolates from the KASPAH study were selected for additional sequencing via the Oxford Nanopore Technologies MinION platform as described previously [17]. These included at least one representative of each unique combination of multi-locus sequence type (ST) and ESBL gene. Representatives of bla $a_{\text {CTX-M-15 }}$ positive KpSC STs identified in the 2017-2020 follow-up period were also subjected to MinION sequencing. Genomes were assembled using Unicycler v0.4.7 [18] and annotated with Prokka v1.14 [19]. Completed genome assemblies were deposited in GenBank and Illumina read sets in the NCBI Sequence Read Archive (accessions in Supplementary Table 1). STs were identified for each genome using Kleborate v1.1 [20] for KpSC, and mlst v2.19 (https://github.com/tseemann/mlst) for Escherichia. AMR genes were detected using Kleborate v1.1 [20].

\section{Identification and comparison of ESBL/carbapenemase plasmids}

For each ESBL or carbapenemase gene identified in multiple genomes, the plasmid sequences harbouring them were compared pairwise using two similarity metrics: (i) Mash similarity (1-[Mash distance], calculated using Mash v2.1.1 [21]), and (ii) gene content Jaccard similarity ([genes in common]/[total genes in either plasmid]). Pairs of plasmids with Mash similarity $\geq 0.98$ and gene content similarity $\geq 0.8$ were designated the same plasmid (thresholds determined empirically, see Supplementary Figure 1). Plasmid replicon markers and MOB genes were detected using Mobtyper v1.4.9 [22], and copy numbers estimated by Unicycler.

For $n=418$ genomes in the 2017-2020 follow-up collection, we used read mapping to determine the presence of Plasmid A, represented by pINF329. Illumina reads were mapped to pINF329 (accession LR890241) using RedDog (https://github.com/scwatts/reddog-nf) to determine coverage and depth of the plasmid sequence as described previously [23]. Genomes were considered Plasmid A-positive if they had $\geq 80 \%$ mapping coverage and $<10$ single nucleotide variants (SNVs) compared to the pINF329 reference sequence ( $n=133$ genomes).

\section{Phylogenetic analyses}

We generated core-genome phylogenies for Plasmid A, and chromosomes of $K$. pneumoniae ST323 $(n=40)$, ST29 $(n=17)$, ST2856 $(n=10)$ and $K$. variicola ST347 $(n=54)$. Illumina reads were 
medRxiv preprint doi: https://doi.org/10.1101/2021.12.20.21268000; this version posted December 27, 2021. The copyright holder for this preprint (which was not certified by peer review) is the author/funder, who has granted medRxiv a license to display the preprint in perpetuity.

It is made available under a CC-BY 4.0 International license .

mapped to completed reference sequences generated from study isolates (pINF329 for Plasmid A, accession LR890241; INF018 for ST323, accession LR890493; INF250 for ST29, accession LR890374; KPN342 for ST2856, accession CP089384; INF345 for ST347, accession LR890399) using RedDog to identify SNVs as described above. For additional context, chromosome SNV alignments were supplemented with genomes of the same ST from public isolate collections [20]. Phylogenies were inferred using RAxML v8.2.9 [24] with a general time-reversible substitution model. See Supplementary Methods for further details.

\section{Results}

Year-long surveillance of KpSC clinical infection (hospital-wide) and carriage (ICU only) identified infections in 303 patients and colonisation in 102 (including 14 with clinical infection) $[13,15]$. WGS identified ESBLs in $47(15 \%)$ infections and $10(10 \%)$ carriage episodes [15]. Additional screening for ESBL+ Enterobacteriaceae in ICU patients during the last three months of the study identified 25 non-KpSC isolates for comparison ( $n=24$ Escherichia coli, $\mathrm{n}=1$ Escherichia marmotae) representing 6 infection and 19 rectal carriage episodes [16].

All ESBL+ isolates were confirmed $3 G C R$, displaying ceftriaxone MIC $>2 \mathrm{mg} / \mathrm{L}$. Seven different acquired ESBL genes were detected in the KpSC isolates; bla $a_{\text {CTX-M-15 }}$ was the most common, present in $85 \%$ of all ESBL+ genomes $(n=62)$ (Figure 1a). All KpSC genomes carrying bla $a_{\mathrm{VEB}-1}$ also carried bla $a_{\mathrm{CTX}-\mathrm{M}-15}$. Six acquired ESBL genes were detected in the Escherichia isolates, again blaстX-M-15 was the most common ( $n=9,37 \%$ of ESBL+ Escherichia) (Figure 1b). Twelve KpSC isolates (all ESBL+) carried carbapenemase genes: bla $a_{\text {oxA-48 }}(\mathrm{n}=8$ genomes, five episodes, all $K$. pneumoniae ST231 and also carrying bla $\left.a_{\mathrm{CTX}-\mathrm{M}-15}\right)$ and bla $a_{\mathrm{IMP}-4}(\mathrm{n}=4$ genomes, two episodes, all $K$. pneumoniae ST340 and also carrying bla $a_{\mathrm{CTX}-\mathrm{M}-15)}$ ). ESBL+ isolates harboured a significantly higher burden of acquired AMR genes than ESBL- ones, amongst both KpSC (median 12 vs $0, p<10^{-15}$ using Wilcoxon rank sum test, one representative per episode) and Escherichia (median 10 vs 2, Wilcoxon test, $p=5.4 \times 10^{-5}$ ) (Figure 2a).

\section{ESBL plasmid diversity}

To determine the genetic context of ESBL genes, we generated complete closed reference sequences for $n=67 / 104 E S B L+$ genomes $(64 \%)$, including at least one for each unique combination of ESBL gene and species/ST, representing $n=48 / 77$ of all ESBL episodes (62\%). Most of the completed KpSC genomes ( $n=48 / 52,92 \%)$ carried a plasmid-borne ESBL gene (including $n=14$ with an additional chromosomal copy); the rest $(n=4 / 52,8 \%)$ carried a chromosomal ESBL gene only (b/a $a_{\mathrm{CTX}-\mathrm{M}-15}$ ). Similarly, amongst Escherichia genomes, $87 \%$ $(n=13 / 15)$ carried a plasmid-borne gene (including $n=2$ with an additional chromosomal copy) and $13 \%(n=2 / 15)$ carried a chromosomal ESBL gene only (b/a $\left.a_{\mathrm{CTX}-\mathrm{M}-15}\right)$.

Using pairwise similarity scores to compare all 61 completed ESBL plasmid sequences (see Methods) we identified 25 distinct plasmids. Those found in only a single genome were labelled with their host isolate, and those found in $\geq 2$ genomes were labelled Plasmid $A$, Plasmid B etc. Each ESBL plasmid was restricted to either KpSC $(n=12)$ or Escherichia $(n=13)$ (Table 1). The majority ( $n=17,68 \%)$ were IncF type plasmids, ranging in size from 45-245 kbp with estimated copy number 1.3-3 per cell, and accounting for $70 \%$ of the bla $a_{\text {CTX-M }}$ genes that were identified (Table 1, Supplementary Table 2). Other notable ESBL plasmids

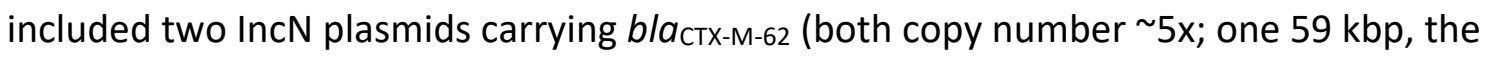


medRxiv preprint doi: https://doi.org/10.1101/2021.12.20.21268000; this version posted December 27, 2021. The copyright holder for this preprint (which was not certified by peer review) is the author/funder, who has granted medRxiv a license to display the preprint in perpetuity.

It is made available under a CC-BY 4.0 International license .

other $102 \mathrm{kbp}$ and also harbouring an IncR replicon marker), and a small (10 kbp) high copy number (16x) plasmid carrying bla $a_{\mathrm{CTX}-\mathrm{M}-14}$ in E. coli ST48 (Table 1, Supplementary Table 2).

Ten of $12 \mathrm{KpSC}$ ESBL plasmids carried additional AMR genes (median 8.5 AMR genes per plasmid); however, only half ( $n=6 / 13$ ) of the Escherichia $\mathrm{ESBL}+$ plasmids carried additional AMR genes (median 6 per plasmid) (Table 1, Supplementary Table 2). Nearly all ( $n=45 / 48$, 93\%) of the completed ESBL plasmid-carrying KpSC genomes carried at least one additional plasmid (range 0-9 plasmids), and 70\% carried at least three (Figure $\mathbf{2 b}$ ). The majority of additional plasmids did not carry AMR genes, except for two STs carrying carbapenemase plasmids: $K$. pneumoniae ST340 with bla $\left.\right|_{\mathrm{IMP}-4}(\mathrm{n}=4$ isolates) and $K$. pneumoniae ST231 with bla ${ }_{\text {OXA-48 }}(\mathrm{n}=8$ isolates) (Supplementary Table 2, Supplementary Text). All of the completed ESBL plasmid-carrying $E$. coli genomes carried at least one additional plasmid (range 1-8) (Figure $\mathbf{2 b}$ ), the majority of which lacked AMR genes ( $n=8 / 13,62 \%$ ).

\section{Plasmid transmission network}

We used the completed genomes to investigate the evidence for nosocomial transmission of ESBL plasmids between distinct KpSC strain backgrounds (defined by ST), by constructing a network in which nodes represent ESBL+ plasmids identified in KpSC (Figure 3). The vast majority of unique ESBL plasmids were detected in either a single genome $(n=13 / 25)$ or a small number of genomes of a single ST ( $n=11 / 25,2-8$ genomes each) (Table 1, Figure 3). However, Plasmid A (which carried bla $a_{\mathrm{CTX}-\mathrm{M}-15}$ ) was identified in 41 isolates belonging to four K. pneumoniae STs (ST323, ST29, ST5822, ST221) and K. variicola (ST347, see Figure 3). Plasmid A was highly conserved between isolates, with median pairwise gene content similarity 0.93 (range 0.84-1) and median Mash distance 0.998 (range 0.996-1; see Figure 3, Supplementary Table 2). Median 0 SNVs were detected amongst Plasmid A sequences (19 identical, range 0-54 SNVs), regardless of host chromosomal ST, with only occasional differences in plasmid gene content (Supplementary Figure 2). Taken together, these data support transmission of Plasmid A between multiple $K$. pneumoniae lineages and one $K$. variicola lineage.

Applying a similar analysis to the carbapenemase plasmids revealed an IncL plasmid (Plasmid M carrying blaoxA-48, Supplementary Table 2) in two different host strains (E. coli ST38 and K. pneumoniae ST231) from the same patient. The sample collection dates were consistent with transfer of Plasmid M from K. pneumoniae ST231 to E. coli ST38 in this patient's gut (Supplementary Figure 3, Supplementary Text).

\section{Dissemination of Plasmid A and contribution to ESBL burden}

Overall Plasmid A was present in $51 \%$ ( $n=29 / 57)$ of KpSC ESBL+ episodes (53\% of ESBL+ infections) during the study period. The remaining $49 \%(n=28 / 57)$ of KpSC ESBL+ episodes were attributed to plasmids/strains isolated from one patient only (Figure 5a). $\mathrm{K}$. pneumoniae ST323 was the most common host strain for Plasmid A $(n=22)$. Plasmid Apositive ST323 were detected throughout the entire study period and accounted for $29 \%$ of ESBL+ KpSC episodes (25.5\% of infections, $50 \%$ of carriage) (Figure 4). Plasmid A-positive ST323 isolates from distinct patients differed from each other by 0-55 chromosomal SNVs (median 22, see Supplementary Figure 4), consistent with clonal transmission of this strain within the hospital network as previously reported [14]. 
medRxiv preprint doi: https://doi.org/10.1101/2021.12.20.21268000; this version posted December 27, 2021. The copyright holder for this preprint (which was not certified by peer review) is the author/funder, who has granted medRxiv a license to display the preprint in perpetuity.

It is made available under a CC-BY 4.0 International license .

We hypothesise that Plasmid A was originally hosted in ST323 and subsequently transmitted into four other KpSC STs. This is supported by identification of an outgroup ST323 genome (EuSCAPE_IT380, accession ERR1217451, isolated in Italy in 2013 [25]) carrying Plasmid A (2 plasmid SNVs, 59 chromosomal SNVs, Supplementary Figure 4). Additionally, two ST29 isolates collected in months 4 and 7 did not carry Plasmid A (INF206 and INF122, Figure 4), and were evolutionarily distant from the 11 Plasmid A-positive ST29 genomes recovered in months 8-12 (INF206=10,341 core genome SNVs, INF122=106 SNVs; Supplementary Figure 4) [14]. Similarly, a Plasmid A-negative K. variicola ST347 isolate collected in month 8 (INF238, Figure 4) was distant to subsequent ST347 isolates (35,020 core genome SNVs; Supplementary Figure 4). Analysis of the Plasmid A backbone sequence showed that the variants present in ST29, ST5822, ST221 and ST347 genomes were clustered in a single subclade of the Plasmid A phylogeny, whereas ST323 variants were more diverse and present both within and outside of this sub-clade (Supplementary Figure 2).

We detected only a single episode each of ST221 and ST5822 with Plasmid A, but the data supported nosocomial transmission of the ST29 and ST347 strains following acquisition of Plasmid A (median chromosomal SNVs between isolates from different patients $=1$ for both STs, range 0-5). Assuming all four STs acquired Plasmid A from ST323, these plasmid transmission events and subsequent onward transmission of the resulting ESBL+ strains would account for $23 \%$ ( $n=13 / 57$ ) of KpSC all ESBL+ episodes ( $28 \%$ of ESBL+ infections) during the one-year study period, including $54 \%$ of those in the last 3 months (Figure 5a,b).

\section{Long-term persistence of Plasmid A in diverse strain backgrounds}

We screened for Plasmid $A$ in additional WGS data from 3GCR KpSC clinical isolates collected 3-6 years later from the same hospital laboratory $(n=418$, representing $92 \%$ of all 3GCR KpSC clinical isolates during March 2017 - Dec 2020). These 418 isolates represented 365 infection episodes (57\% urinary tract, 13\% bacteraemia, 12\% respiratory, 5.8\% wound/soft tissue). Plasmid A was identified in 35\% of all sequenced 3GCR isolates and $21.2 \%$ of all 3 GCR infection episodes (24\%, $21 \%, 42 \%$ and $8.5 \%$ of $3 G C R$ urinary, bacteraemia, wound/soft tissue, and respiratory episodes, respectively). We observed the same three expanded STs seen in the original study ( $n=11$ ST323, $n=3$ ST29, $n=69$ ST347), as well as two additional STs ( $n=11$ ST2856, $n=1$ ST5823) (Figure 5c). Phylogenetic analysis of the host chromosomes was consistent with persistence of the plasmid during long-term local clonal expansion of the ST323, ST29 and ST347 host strains (Supplementary Figure 4). Inspection of completed genome sequences for one genome per ST (KPN029, KPN110, KPN392, KPN342, KPN692) confirmed that the more recent isolates carried Plasmid A, with few structural changes (Supplementary Figure 5a). Plasmid A was most prevalent from March 2017 to March 2018, accounting for 52\% of 3GCR episodes ( $n=62 / 120$, Figure 5c). From April 2018 onwards, Plasmid A episodes were rare $(<10 \%)$, except for a cluster of infections between September 2018 and May 2019 during which time Plasmid A-positive ST347 accounted for $27.5 \%$ of 3 GCR infections (Figure $5 c$ ).

\section{Discussion}

Here, we present a systematic comparison of ESBL strain and plasmid transmission over a year in a single hospital network. Whilst there was no evidence of plasmid transmission for most ESBL+ plasmids, Plasmid A was the exception and we speculate that ST323 was the original donor strain. Whilst we cannot be certain that Plasmid $A$ transmission events 
medRxiv preprint doi: https://doi.org/10.1101/2021.12.20.21268000; this version posted December 27, 2021. The copyright holder for this

preprint (which was not certified by peer review) is the author/funder, who has granted medRxiv a license to display the preprint in perpetuity.

It is made available under a CC-BY 4.0 International license .

occurred within our hospital (ST323 has been detected in other Melbourne hospitals [8]), it is most likely that they occurred in a hospital setting under selective pressure from antibiotics, since ESBL KpSC is known to be relatively rare outside of the hospital environment in Australia and other high-income countries [26,27].

Our results indicate that Plasmid $A$ is stable in at least some strain backgrounds, with three out of six putative recipient strains going on to spread in the hospital in parallel with the dissemination of Plasmid A-positive ST323. Compared with the other ESBL+ plasmids identified in this study, which showed no evidence of transfer between strains, Plasmid $A$ likely has properties that (i) make it efficient at horizontal transfer, and/or (ii) reduce the fitness cost and thus facilitate its stable maintenance. Plasmid $A$ is very similar to the

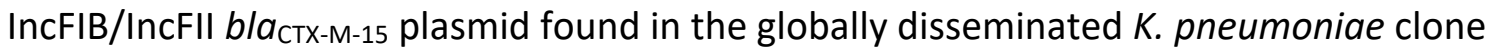
ST307 (pKPN-307, median Mash distance 0.99, 70\% gene similarity to Plasmid A, with some differences in gene order; Supplementary Figure $\mathbf{5 b}$ ), which has been stably maintained for decades [28]. pKPN-307 carries five distinct virulence clusters that are hypothesised to aid long term survival of ST307 outside of the human host [29]; all five of these clusters are conserved in Plasmid $A$, in addition to heavy metal resistance operons (Supplementary Figure 5c). Other IncFIB/IncFII plasmids detected in the globally distributed $K$. pneumoniae ST258 also carry many of these genes [30], suggesting that they may be a feature of this plasmid background. Understanding what plasmid and/or host strain properties enable stable maintenance of large AMR plasmids within a particular genetic background is vital to improving our understanding of how AMR strains emerge and persist [31].

ESBL infections contribute to increased length of hospital stays, resulting in higher healthcare costs [32]. Models examining genomic surveillance have been shown to reduce overall healthcare costs [33], but have not considered the impact of plasmid transmission on AMR burden. Here, prevention of onward transmission of ST323 would have reduced the opportunity for Plasmid A to spread and create novel ESBL+ strains. This could potentially have prevented half of all ESBL episodes in the primary one-year study period, and one-fifth of all 3GCR episodes in the follow-up period 3-6 years later. Whilst our study focused on ESBL plasmids, those carrying carbapenemases transfer via the same mechanisms and show similar transmission dynamics. Like ESBL plasmids, some carbapenemase plasmids have been found to transmit amongst the Enterobacteriaceae in hospital environments [34,35], and in particular Klebsiella has been known to harbour multiple ESBL and carbapenemase plasmids in a single cell $[36,37]$. This study highlights the need for improved approaches to detect plasmid transmission using genomic data within an infection control framework.

\section{Funding}

This work was supported by the National Health and Medical Research Council of Australia (Project Grant 1043822 to K.E.H. and A.W.J.J., Investigator Grant APP1176192 to K.L.W), the Viertel Charitable Foundation of Australia (Senior Medical Research Fellowship to K.E.H), and the Bill \& Melinda Gates Foundation OPP1175797. Under the grant conditions of the Foundation, a Creative Commons Attribution 4.0 Generic License has already been assigned to the Author Accepted Manuscript version that might arise from this submission.

\section{Conflict of Interest}

The authors declare no conflicts of interest. 
medRxiv preprint doi: https://doi.org/10.1101/2021.12.20.21268000; this version posted December 27, 2021. The copyright holder for this preprint (which was not certified by peer review) is the author/funder, who has granted medRxiv a license to display the preprint in

It is made available under a CC-BY 4.0 International license .

Table 1: Unique ESBL plasmids found in this study. \#Pt, number of patients; \#G, number of genomes (completed \& draft). Kp - K. pneumoniae; Kv - K. variicola; Ec - E. coli; Em - E. marmotae.

\begin{tabular}{|c|c|c|c|c|c|c|c|c|c|}
\hline Plasmid & ESBL & \#Pt & \#G & Organisms & $\begin{array}{l}\text { Median } \\
\text { size (bp) }\end{array}$ & $\begin{array}{l}\text { Inc } \\
\text { type(s) }\end{array}$ & МОВ & $\begin{array}{l}\text { Median } \\
\text { copy } \\
\text { number }\end{array}$ & $\begin{array}{l}\text { \# AMR } \\
\text { classes } \\
\text { (genes) }\end{array}$ \\
\hline \multicolumn{10}{|c|}{ KpSC ESBL Plasmids } \\
\hline Plasmid A & $b / a_{\mathrm{CTX}-\mathrm{M}-15}$ & 18 & 39 & $\begin{array}{l}\text { Kp (4 STs) } \\
\text { Kv ST347 }\end{array}$ & 243,577 & FIB, FII & $\mathrm{F}$ & 1.30 & $3-5(5-8)$ \\
\hline Plasmid B & $\begin{array}{l}b^{b} a_{\mathrm{CTX}-\mathrm{M}-15} \\
\text { bla }_{\mathrm{VEB}-1}\end{array}$ & 4 & 6 & Kp ST231 & 128,238 & C (ST3) & $\mathrm{H}$ & 1.49 & $6(12)$ \\
\hline Plasmid C & $b / a_{\mathrm{CTX}-\mathrm{M}-15}$ & 4 & 4 & Kp ST491 & 190,324 & FIA, FII & $\mathrm{F}$ & 1.49 & $6(6)$ \\
\hline Plasmid D & $b / a_{\mathrm{CTX}-\mathrm{M}-15}$ & 3 & 8 & Kp ST340 & 89,345 & FIA, R & - & 2.20 & $5(9)$ \\
\hline pINF044 & bla CTX-M-15 & 1 & 1 & Kp ST437 & 227,214 & FIB, FII & $\mathrm{F}$ & 1.07 & $6(9)$ \\
\hline pINF161 & $b / a_{\mathrm{CTX}-\mathrm{M}-14}$ & 1 & 1 & Kp ST661 & 89,062 & FIIA & $\mathrm{P}$ & 1.15 & $0(0)$ \\
\hline Plasmid E & $b / a_{\mathrm{CTX}-\mathrm{M}-14}$ & 3 & 3 & Kp ST17 & 214,317 & FIB, FII & $\mathrm{F}$ & 1.24 & $7(10-12)$ \\
\hline Plasmid F & bla CTX-M-14 & 2 & 2 & Kp ST3062 & 159,592 & $\begin{array}{l}\text { FIB, } \\
\text { FIIA, FII, } \\
\text { FIA }\end{array}$ & $\mathrm{F}$ & 2.58 & $5(8)$ \\
\hline Plasmid G & $b / a_{\mathrm{CTX}-\mathrm{M}-62}$ & 2 & 2 & Kp ST15 & 102,016 & $N, R$ & $P, F$ & 5.97 & $8(11)$ \\
\hline pINF223 & $b / a_{\mathrm{CTX}-\mathrm{M}-3}$ & 1 & 1 & Kp ST3072 & 60,529 & FII & $\mathrm{P}$ & 2.98 & $2(2)$ \\
\hline pKSB1_1B & $b / a_{\text {СТX-M- } 55}$ & 1 & 1 & Kp ST1213 & 113,743 & 12 & $P$ & 1.30 & $0(0)$ \\
\hline pINF058 & $b / a_{\mathrm{SHV}-12}$ & 1 & 1 & Kv ST3076 & 279,735 & $\mathrm{H}$ & $\mathrm{H}$ & 1.55 & $8(8)$ \\
\hline \multicolumn{10}{|c|}{ Escherichia ESBL plasmids } \\
\hline pMSB1_1A & $b / a_{\text {CTX-M-15 }}$ & 1 & 1 & Ec ST617 & 173,787 & $\begin{array}{l}\text { FIB, } \\
\text { FIIA, FII, } \\
\text { FIA }\end{array}$ & $\mathrm{F}$ & 1.53 & $7(10)$ \\
\hline pMSB1_9l & $b / a_{\text {СТХ-M-15 }}$ & 1 & 1 & Ec ST10 & 44,618 & FIIA, FII & $F$ & 1.30 & $0(0)$ \\
\hline pMINF_8D & bla CTX-M-15 & 1 & 1 & Ec ST10 & 115,278 & $\begin{array}{l}\text { unknow } \\
\mathrm{n}\end{array}$ & none & 1.72 & $0(0)$ \\
\hline pMINF_1D & $b / a_{\text {CTX-M-15 }}$ & 1 & 1 & Ec ST141 & 125,802 & $\begin{array}{l}\text { FIB, } \\
\text { FIIA, FII, } \\
\text { FIA }\end{array}$ & $\mathrm{F}$ & 1.55 & $1(1)$ \\
\hline Plasmid H & $b / a_{\text {СTX-M-14 }}$ & 2 & 2 & Ec ST48 & 10,057 & none & none & 15.81 & $2(2)$ \\
\hline pMINF_2E & bla CTX-M-14 & 1 & 1 & Ec ST602 & 207,369 & $\begin{array}{l}\text { FIB, } \\
\text { FIIA, FII }\end{array}$ & $P, F$ & 1.58 & $0(0)$ \\
\hline Plasmid I & $b / a_{\text {CTX-M-14 }}$ & 2 & 2 & Ec ST38 & 70,350 & FIIA, FII & $\mathrm{F}$ & 2.71 & $0(0)$ \\
\hline pMSB1_5C & $b / a_{\text {CTX-M-14 }}$ & 1 & 1 & Em ST3727 & 70,361 & FIIA, FII & $\mathrm{F}$ & 2.63 & $0(0)$ \\
\hline
\end{tabular}


medRxiv preprint doi: https://doi.org/10.1101/2021.12.20.21268000; this version posted December 27, 2021. The copyright holder for this preprint (which was not certified by peer review) is the author/funder, who has granted medRxiv a license to display the preprint in perpetuity.

It is made available under a CC-BY 4.0 International license.

\begin{tabular}{|c|c|c|c|c|c|c|c|c|c|}
\hline Plasmid J & $b / a_{\text {CTX-M-27 }}$ & 2 & 3 & Ec ST131 & 112,822 & $\begin{array}{l}\text { FIB, } \\
\text { FIIA, FII, } \\
\text { FIA }\end{array}$ & $F$ & 1.95 & $0(0)$ \\
\hline Plasmid K & $b / a_{\text {CTX-M-27 }}$ & 1 & 2 & Ec ST38 & 160,498 & $\begin{array}{l}\text { FIB, } \\
\text { FIIA, FII, } \\
\text { FIA }\end{array}$ & $\mathrm{F}$ & 1.91 & $6(9)$ \\
\hline pMINF_9A & $b / a_{\text {CTX-M-27 }}$ & 1 & 1 & Ec ST648 & 139,312 & $\begin{array}{l}\text { FIB, } \\
\text { FIIA, FII, } \\
\text { FIA }\end{array}$ & $F$ & 1.79 & $5(7)$ \\
\hline Plasmid L & $b / a_{\text {СТX-M- } 62}$ & 2 & 2 & Ec ST176 & 59,604 & $\mathrm{~N}$ & $\mathrm{~F}$ & 4.83 & $5(5)$ \\
\hline Plasmid O & $b / a_{\mathrm{CMY}-42}$ & 2 & 2 & Ec ST354 & 47,582 & I1 & $P$ & 2.05 & $0(0)$ \\
\hline
\end{tabular}


medRxiv preprint doi: https://doi.org/10.1101/2021.12.20.21268000; this version posted December 27, 2021. The copyright holder for this preprint (which was not certified by peer review) is the author/funder, who has granted medRxiv a license to display the preprint in perpetuity.

\section{Figures}

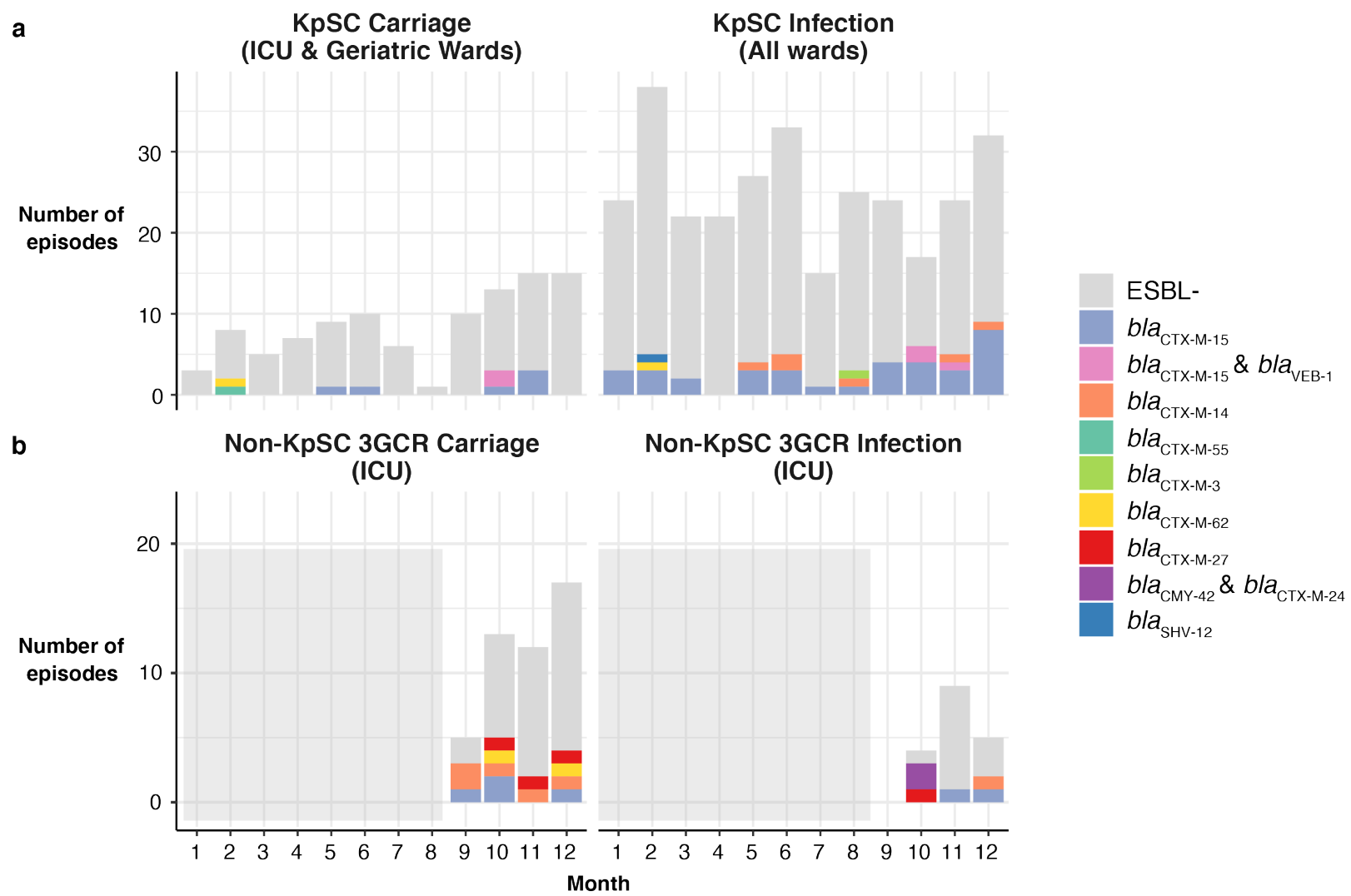

Figure 1: Number of carriage and infection episodes detected per month during the yearlong KASPAH surveillance study. a, KpSC isolates (regardless of 3GCR status); $\mathbf{b}, 3$ GCR nonKpSC Enterobacteriaceae (collected in ICU and during the final three months only). Bars are coloured by acquired ESBL gene, as per legend. Light grey boxes in panel $\mathbf{b}$ indicate no data available for that time period.

a

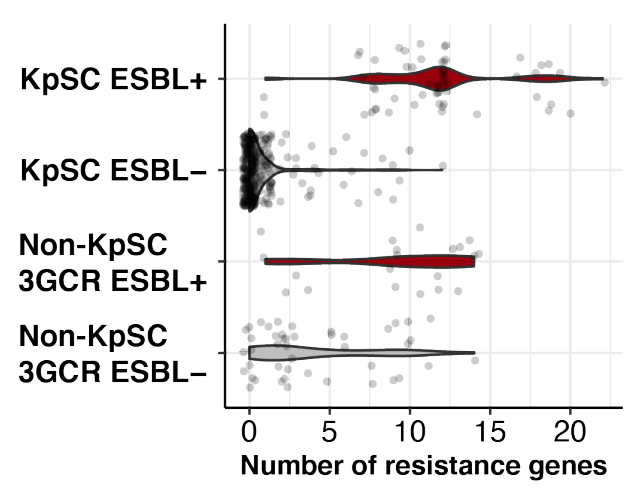

b

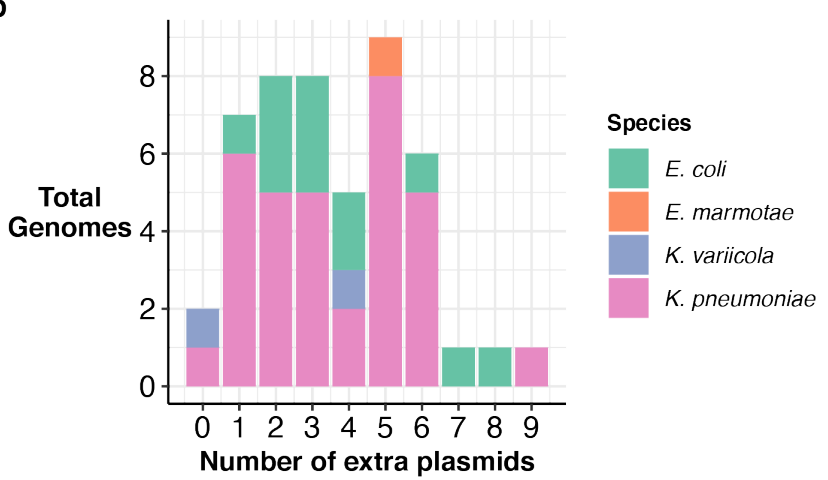

Figure 2: Acquired AMR gene burden and plasmid burden. a, Distribution of acquired AMR genes across isolates collected in the year-long KASPAH study, stratified by sample group (KpSC, capturing both 3GCR and susceptible isolates; 3GCR, capturing only 3GCR isolates of non-Klebsiella Enterobacteriaceae species) and acquired ESBL status. Violin plots are coloured by ESBL status (ESBL+, red; ESBL-, grey). b, Histogram showing the distribution of non-ESBL plasmid counts for ESBL plasmid-positive genomes. Bars are coloured by species as per legend. 
medRxiv preprint doi: https://doi.org/10.1101/2021.12.20.21268000; this version posted December 27, 2021. The copyright holder for this preprint (which was not certified by peer review) is the author/funder, who has granted medRxiv a license to display the preprint in perpetuity.

It is made available under a CC-BY 4.0 International license .

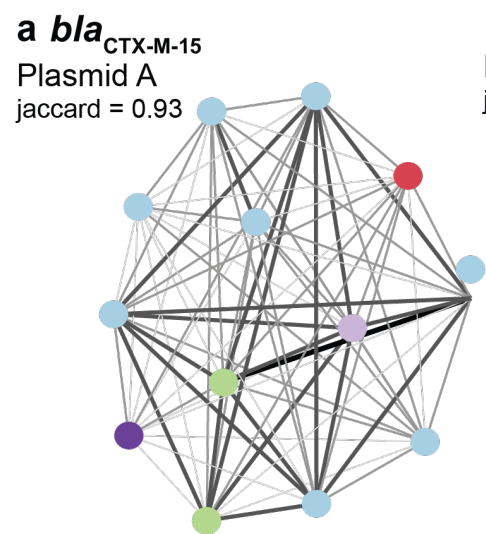

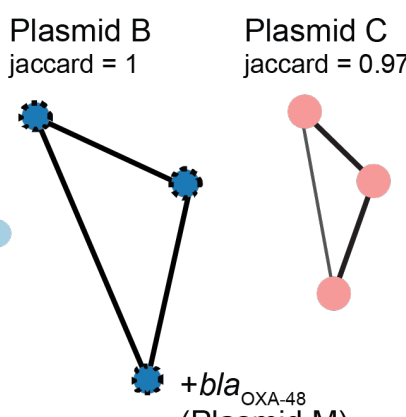

(Plasmid M)
Plasmid D

jaccard $=0.99$

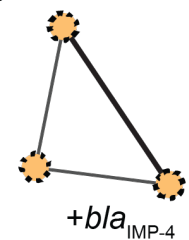

(Plasmid N)

pINF044

ST437

b bla CTX-M-14

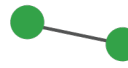

Plasmid E Plasmid F jaccard $=0.94$ ST3062
pINF161 ST661 c other ESBL genes

$$
\begin{array}{cccc}
\text { bla }_{\text {CTX-M-62 }} & \text { bla } a_{C T X-M-3} & b l a_{C T X-M-55} & b l a_{S H V-12} \\
& & & \\
\text { Plasmid G } & \text { pINF223 } & \text { pKSB1_1B } & \text { pINF058 } \\
\text { ST15 } & \text { ST3072 } & \text { ST1213 } & \text { ST3076 }
\end{array}
$$

Plasmid gene content similarity $\geq 0.8,<0.9$ $\geq 0.9,<0.95$

$-\geq 0.95,<1$

$-1$

ST

ST323

ST29

ST347 (K. variicola)

ST5822

ST221

ST231

ST491

ST340

ST17/ST5871

ESBL gene location

$\because$ plasmid \& chromsome

Figure 3: ESBL plasmid cluster network for all completed KpSC ESBL+ genomes. a, bla 15 plasmids; b, bla $a_{\mathrm{CTX}-\mathrm{M}-14}$ plasmids; $\mathbf{c}$, other detected ESBLs. Each node represents a completed genome (from one representative isolate per patient), coloured by the bacterial host cell ST as per legend. Dashed outline surrounding dot indicates if the ESBL is carried on both a plasmid and the chromosome. Nodes are connected if they share a similar plasmid sequence, defined as mash similarity $\geq 0.98$ and gene content similarity $\geq 0.8$ (see Supplementary Figure 1); line colour and width indicate plasmid gene content similarity (as per legend). Clusters comprising $\geq 2$ genomes are labelled with the median jaccard gene similarity score. ' $+b / a_{\mathrm{OXA}-48}$ (Plasmid M)' and ' $+b / a_{\mathrm{IMP}-4}$ (Plasmid N)' indicate STs that carry an additional carbapenemase plasmid (details in Supplementary Table 2). 
medRxiv preprint doi: https://doi.org/10.1101/2021.12.20.21268000; this version posted December 27,2021 . The copyright holder for this preprint (which was not certified by peer review) is the author/funder, who has granted medRxiv a license to display the preprint in perpetuity.

It is made available under a CC-BY 4.0 International license .
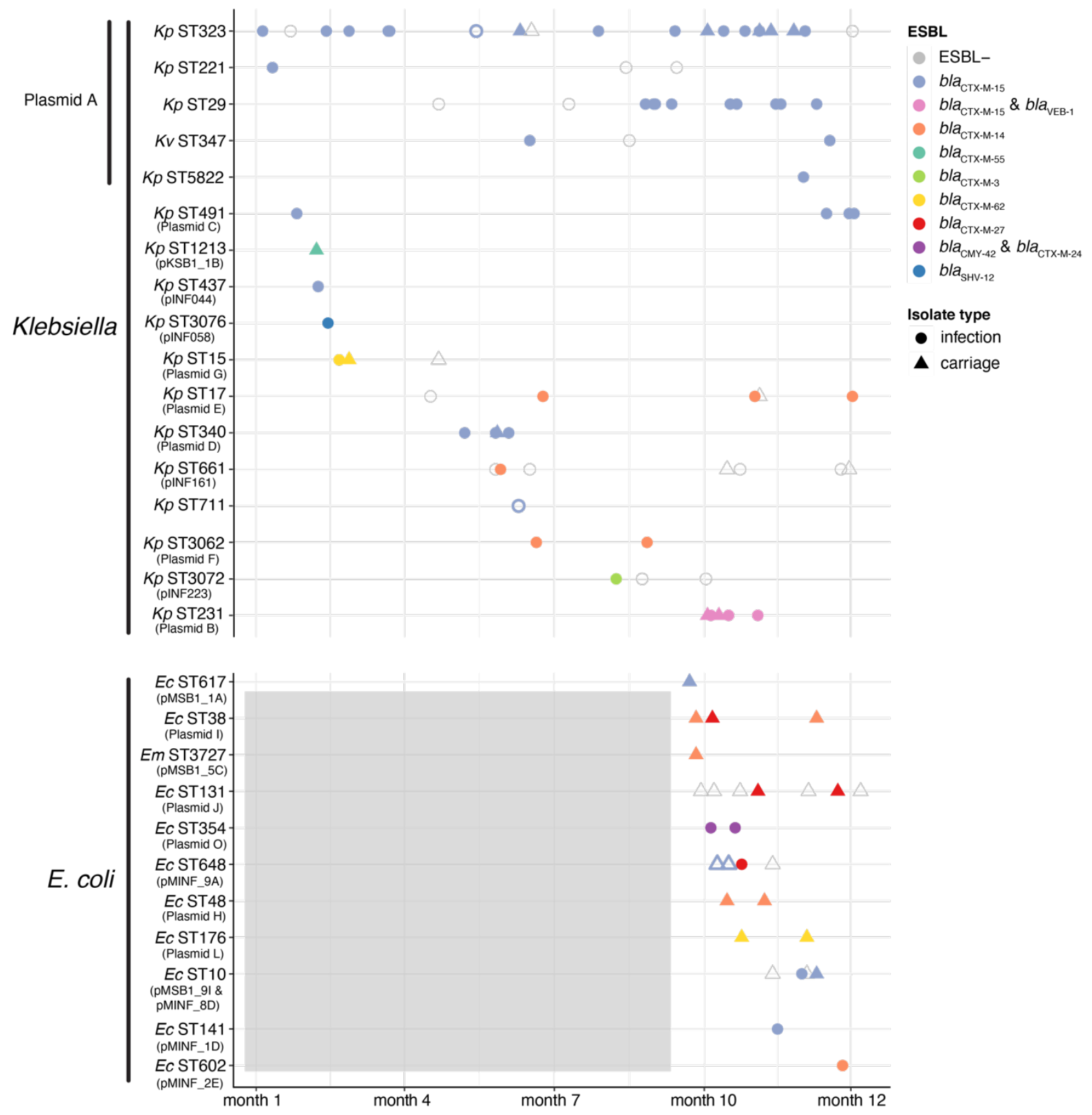

Figure 4: Timeline of ESBL+ infection and carriage episodes. Each episode is represented by a single isolate, grouped in rows by the isolate ST. Colours indicate the ESBL enzyme encoded in the genome (as per legend), and shapes indicate whether the episode was carriage (circle) or infection (triangle). Presence of the ESBL plasmid most commonly associated with the ST is indicated by filled shapes (with plasmid name listed under ST on the $y$-axis). ESBL genes on the chromosome rather than plasmid are indicated by shapes with no fill and a coloured outline. Grey box indicates that no data was available for this period for the Escherichia STs. Kp - K. pneumoniae; Kv - K. variicola; Ec - E. coli; Em - E. marmotae. 
medRxiv preprint doi: https://doi.org/10.1101/2021.12.20.21268000; this version posted December 27, 2021. The copyright holder for this preprint (which was not certified by peer review) is the author/funder, who has granted medRxiv a license to display the preprint in perpetuity.

a

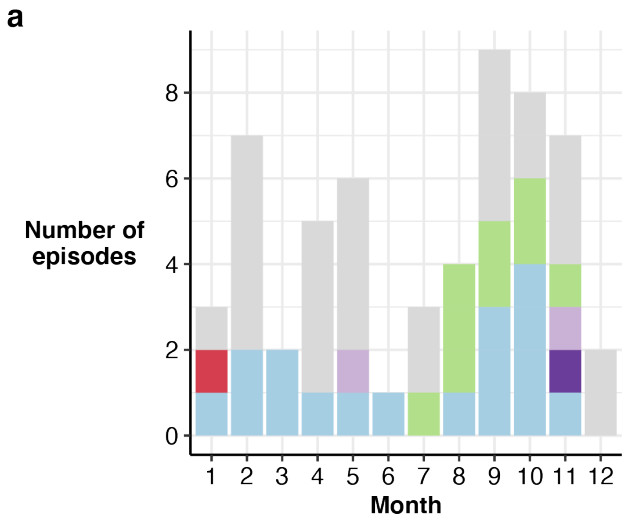

b

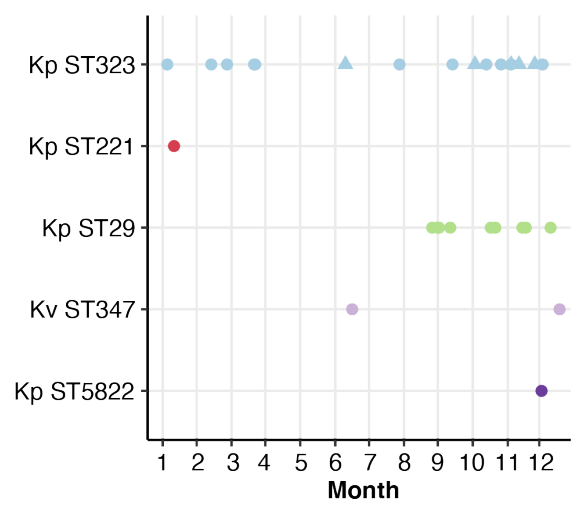

2019

2018

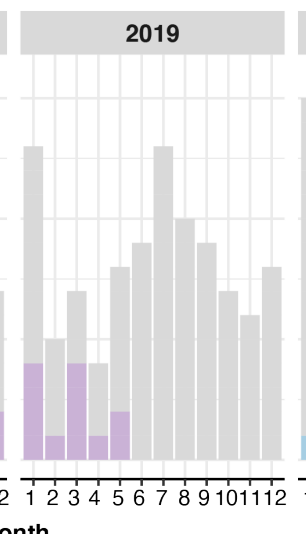

2020

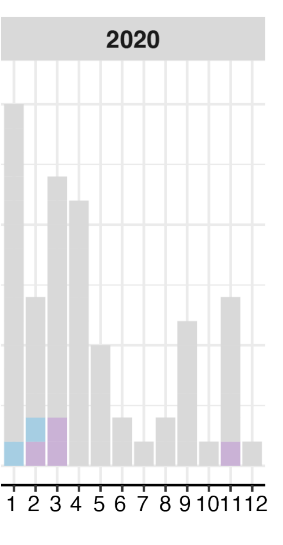

ST

Other ESBL

ST29

ST347

ST221

ST5822

ST323

ST2856

ST5823

isolate type

$\Delta$ carriage

- infection

Figure 5: Presence of Plasmid A over time. a, Bar height indicates total number of ESBL episodes across the initial year-long study period, by month. Bars are coloured by Plasmid $A$ positive ST episodes as per legend, and grey for non-Plasmid A ESBL episodes. $\mathbf{b}$, Timeline of Plasmid A positive episodes during the initial year-long study period. Each point represents an episode, with colour indicating ST (as per legend) and shape indicating whether the episode was infection (circle) or carriage (triangle). c, Bar height indicates the total number of 3GCR KpSC episodes per month from March 2017 - December 2020. Bars are coloured by ST as per legend if the episode was positive for Plasmid A. 
medRxiv preprint doi: https://doi.org/10.1101/2021.12.20.21268000; this version posted December 27, 2021. The copyright holder for this preprint (which was not certified by peer review) is the author/funder, who has granted medRxiv a license to display the preprint in perpetuity.

It is made available under a CC-BY 4.0 International license .

\section{References}

1. Cassini A, Plachouras D, Eckmanns T, et al. Burden of Six Healthcare-Associated Infections on European Population Health: Estimating Incidence-Based Disability-Adjusted Life Years through a Population Prevalence-Based Modelling Study. Plos Med 2016; 13:e1002150e1002150.

2. World Health Organisation. Global Priority List of Antibiotic-Resistant Bacteria to Guide Research, Discovery, and Development of New Antibiotics. 2017. Available at: http://www.who.int/medicines/publications/global-priority-list-antibiotic-resistantbacteria/en/.

3. Baker S, Thomson N, Weill FX, Holt KE. Genomic insights into the emergence and spread of antimicrobial-resistant bacterial pathogens. Science 2018; 360:733-738.

4. Navon-Venezia S, Kondratyeva K, Carattoli A. Klebsiella pneumoniae: A major worldwide source and shuttle for antibiotic resistance. Fems Microbiol Rev 2017; 41:252-275.

5. Wyres KL, Holt KE. Klebsiella pneumoniae as a key trafficker of drug resistance genes from environmental to clinically important bacteria. Curr Opin Microbiol 2018; 45:131-139.

6. Lee RS, Silva AG da, Baines SL, et al. The changing landscape of vancomycin-resistant Enterococcus faecium in Australia: a population-level genomic study. J Antimicrob Chemoth 2018; 73:3268-3278.

7. Sherry NL, Lane CR, Kwong JC, et al. Genomics for Molecular Epidemiology and Detecting Transmission of Carbapenemase-Producing Enterobacterales in Victoria, Australia, 2012 to 2016. J Clin Microbiol 2019; 57.

8. Sherry NL, Lee RS, Gorrie CL, et al. Genomic interrogation of the burden and transmission of multidrug-resistant pathogens within and across hospital networks. Biorxiv 2019; :764787-764787.

9. Sheppard AE, Stoesser N, Wilson DJ, et al. Nested Russian Doll-Like Genetic Mobility Drives Rapid Dissemination of the Carbapenem Resistance Gene blaKPC. AAC 2016; 60:3767-3778.

10. Conlan S, Park M, Deming C, et al. Plasmid dynamics in KPC-positive Klebsiella pneumoniae during long-term patient colonization. Mbio 2016; 7:e00742-16.

11. Decraene V, Phan HTT, George R, et al. A large, refractory nosocomial outbreak of klebsiella pneumoniae carbapenemase-producing Escherichia coli demonstrates carbapenemase gene outbreaks involving sink sites require novel approaches to infection control. AAC 2018; 62:785-785.

12. Chng KR, Li C, Bertrand D, et al. Cartography of opportunistic pathogens and antibiotic resistance genes in a tertiary hospital environment. Nat Med 2020; 26:941-951. 
medRxiv preprint doi: https://doi.org/10.1101/2021.12.20.21268000; this version posted December 27, 2021. The copyright holder for this preprint (which was not certified by peer review) is the author/funder, who has granted medRxiv a license to display the preprint in perpetuity.

It is made available under a CC-BY 4.0 International license .

13. Gorrie CL, Mirceta M, Wick RR, et al. Gastrointestinal carriage is a major reservoir of $\mathrm{K}$. pneumoniae infection in intensive care patients. Clin Infect Dis 2017; 65:208-215.

14. Gorrie CL, Mirceta M, Wick RR, et al. Antimicrobial-resistant Klebsiella pneumoniae carriage and infection in specialized geriatric care wards linked to acquisition in the referring hospital. Clin Infect Dis 2018; 67:161-170.

15. Gorrie CL, Mirceta M, Wick RR, et al. Genomic dissection of the bacterial population underlying Klebsiella pneumoniae infections in hospital patients: insights into an opportunistic pathogen. Medrxiv 2021; :2021.12.02.21267161.

16. Wyres KL, Hawkey J, Mirčeta M, et al. Genomic surveillance of antimicrobial resistant bacterial colonisation and infection in intensive care patients. BMC Infect Dis 2021; 21:683.

17. Wick RR, Judd LM, Gorrie CL, Holt KE. Completing bacterial genome assemblies with multiplex MinION sequencing. Microb Genom 2017; 3:e000132-e000132.

18. Wick RR, Judd LM, Gorrie CL, Holt KE. Unicycler: Resolving bacterial genome assemblies from short and long sequencing reads. Plos Comput Biol 2017; 13:e1005595-e1005595.

19. Seemann T. Prokka: rapid prokaryotic genome annotation. Bioinformatics 2014; 30:2068-2069.

20. Lam MMC, Wick RR, Watts SC, Cerdeira LT, Wyres KL, Holt KE. A genomic surveillance framework and genotyping tool for Klebsiella pneumoniae and its related species complex. Nat Commun 2021; 12:4188.

21. Ondov BD, Treangen TJ, Melsted $P$, et al. Mash: fast genome and metagenome distance estimation using MinHash. Genome Biol 2016; 17:132-132.

22. Robertson J, Nash JHE. MOB-suite: software tools for clustering, reconstruction and typing of plasmids from draft assemblies. Microb Genom 2018; 4.

23. Holt KE, Wertheim H, Zadoks RN, et al. Genomic analysis of diversity, population structure, virulence, and antimicrobial resistance in Klebsiella pneumoniae, an urgent threat to public health. Proc National Acad Sci 2015; 112:E3574-E3581.

24. Stamatakis A. RAxML version 8: a tool for phylogenetic analysis and post-analysis of large phylogenies. Bioinformatics 2014; 30:1312 1313-1312 1313.

25. David S, Reuter S, Harris SR, et al. Epidemic of carbapenem-resistant Klebsiella pneumoniae in Europe is driven by nosocomial spread. Nat Microbiol 2019; 4:1-1.

26. Arcilla MS, Hattem JM van, Haverkate MR, et al. Import and spread of extendedspectrum $\beta$-lactamase-producing Enterobacteriaceae by international travellers (COMBAT study): a prospective, multicentre cohort study. Lancet Infect Dis 2017; 17:78-85. 
medRxiv preprint doi: https://doi.org/10.1101/2021.12.20.21268000; this version posted December 27, 2021. The copyright holder for this preprint (which was not certified by peer review) is the author/funder, who has granted medRxiv a license to display the preprint in perpetuity

It is made available under a CC-BY 4.0 International license.

27. Raffelsberger N, Hetland MAK, Svendsen K, et al. Gastrointestinal carriage of Klebsiella pneumoniae in a general adult population in Norway: a cross-sectional study of risk factors and bacterial genomic diversity. Medrxiv 2021; :2021.02.06.21251253.

28. Wyres KL, Hawkey J, Hetland MAK, et al. Emergence and rapid global dissemination of CTX-M-15-associated Klebsiella pneumoniae strain ST307. J Antimicrob Chemoth 2019; 74:577-581.

29. Villa L, Feudi C, Fortini D, et al. Diversity, virulence, and antimicrobial resistance of the KPC-producing Klebsiella pneumoniae ST307 clone. Microb Genom 2017; 3:e000110.

30. Garcia-Fernandez A, Villa L, Carta C, et al. Klebsiella pneumoniae ST258 Producing KPC-3 Identified in Italy Carries Novel Plasmids and OmpK36/OmpK35 Porin Variants. Antimicrob Agents Ch 2012; 56:2143 2145-2143 2145.

31. Jordt H, Stalder T, Kosterlitz O, Ponciano JM, Top EM, Kerr B. Coevolution of hostplasmid pairs facilitates the emergence of novel multidrug resistance. Nat Ecol Evol 2020; 4:863-869.

32. Lee XJ, Stewardson AJ, Worth LJ, Graves N, Wozniak TM. Attributable length of stay, mortality risk and costs of bacterial healthcare-associated infections in Australia: a retrospective case-cohort study. Clin Infect Dis 2020; :ciaa1228-.

33. Gordon LG, Elliott TM, Forde B, et al. Budget impact analysis of routinely using wholegenomic sequencing of six multidrug-resistant bacterial pathogens in Queensland, Australia. BMJ Open 2021; 11:e041968-e041968.

34. León-Sampedro R, DelaFuente J, Díaz-Agero C, et al. Pervasive transmission of a carbapenem resistance plasmid in the gut microbiota of hospitalized patients. Nat Microbiol 2021; :1-11.

35. Ledda A, Cummins M, Shaw LP, et al. Hospital outbreak of carbapenem-resistant Enterobacteriales associated with an OXA-48 plasmid carried mostly by Escherichia coli ST399. Biorxiv 2020; :2020.06.15.148189-2020.06.15.148189.

36. Heiden SE, Hübner N-O, Bohnert JA, et al. A Klebsiella pneumoniae ST307 outbreak clone from Germany demonstrates features of extensive drug resistance, hypermucoviscosity, and enhanced iron acquisition. Genome Med 2020; 12:113.

37. Wyres KL, Lam MMC, Holt KE. Population genomics of Klebsiella pneumoniae. Nat Rev Microbiol 2020; 18:344-359. 